\title{
POSTCOLONIAL INDUSTRIAL HERITAGE IN NORTH AFRICA: INVESTIGATIONS AND INSIGHTS INTO THE CITY OF CASABLANCA, MOROCCO
}

\author{
CHAIMA SEDDIKI, JEREMY CENCI \& ISABELLE DE SMET \\ Faculty of Architecture and Urban Planning, University of Mons, Belgium
}

\begin{abstract}
Casablanca, which was the laboratory for Neo-Classical, Neo-Moorish, Art-Deco and Bauhaus architecture, is plundering its past and disposing of its colonial industrial heritage. The lack of inventories, tools and expert structures to evaluate this heritage works in favor of the real estate speculation that is taking over strategic post-industrial territories in a generally carefree manner. The notion of "industrial heritage" in Moroccan culture is not very well known, and the status of the heritage of "the other" is rather complex. But through our inductive methodology and the practice of a DownUp process within the territory of action, a sizeable dimension has emerged from the field, and has been used as a measure. This is the human and social dimension of the postcolonial industrial heritage. The approach of the citizens, with their observations and verbalizations being placed at the heart of the industrial heritage, reveals, for the first time, the identity, historical, memory and cognitive values of the postcolonial industrial heritage. A significant change is taking place. The values attributed to this industrial heritage by the citizens neutralizes the colonial fact, legitimizes the work of the colonists and even raises it to the rank of heritage. Reconciliation has been made and the status of the heritage of the 'other' clarified. Today, the human and social dimension constitutes a real turning point in the field of heritage in Morocco. The post-colonial industrial heritage is recognized by one of the main actors of heritage, by the citizens. This article is based on research carried out over the past five years combining Qualitative Methodology and Grounded Theory on the industrial zones of East Casablanca and Mohammedia, the cradle of Moroccan industry.

Keywords: heritage, Morocco, Casablanca, industrial wasteland.
\end{abstract}

\section{INTRODUCTION}

Morocco has experienced several upheavals since its independence in 1956. The major domestic changes began under King Hassan II and were later extended by King Mohammed VI who, since his coronation in 1999, has made social and development projects a priority. These projects have resulted in the opening of huge social, economic, touristic, and industrial projects in the twelve regions of Morocco. It is within this framework that the four imperial cities, Fez, Meknes, Rabat and Marrakech, have been able to benefit from development projects focusing on the reinforcement of the preservation, safeguarding and rehabilitation of their respective tangible and intangible heritage. But what about the post-colonial industrial heritage of Casablanca, the country's business capital?

Interest in heritage in Morocco has a long history. At the institutional level, the starting point is the Cherifian Dahir (Law in Arabic) of 1912, relating to the conservation of historical monuments and listings. The law has undergone several modifications since then (the Dahir 1945 and the Dahir 1980).

The brief analysis of the content of the legislation explains the interest in heritage shown by the imperial cities, but also demonstrates the inadequacy of the texts concerning the architectural heritage of the new cities and the industrial heritage, works of the French protectorate. The vestiges of the post-Protectorate architecture, apart from some public buildings in the city center, do not meet any criteria and do not rise to the level of national 
heritage. Several cities, and mainly Casablanca, are thus becoming the scenes of the decay of this architecture, sometimes for speculative reasons, sometimes out of simple ignorance.

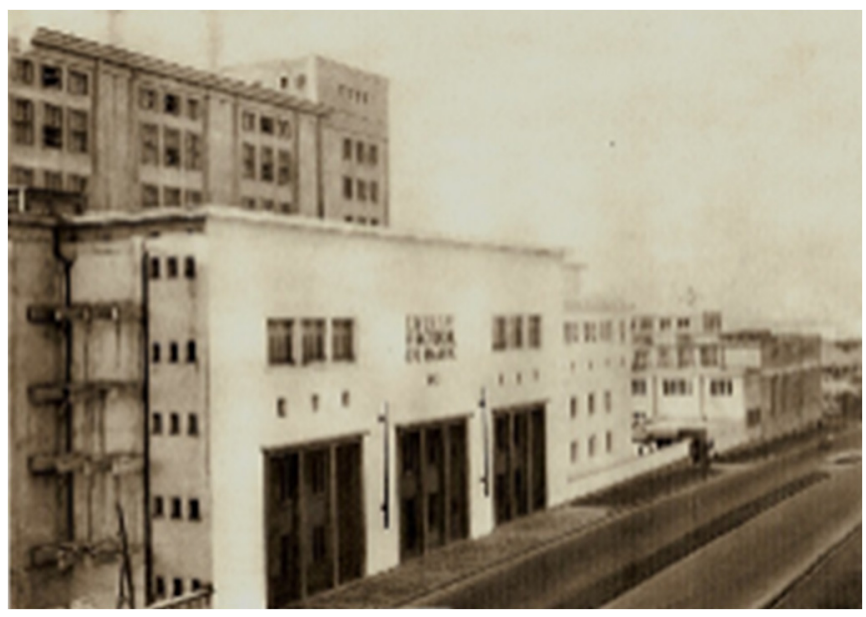

Figure 1: Former installations of the national water and electricity office (O.N.E.E), called the Southern Power Station of Roches Noires, 1952, (C) unknown.

In 2013, a new legal project reinforces and replaces the provisions stipulated by the Dahir of 1980. This project aims "to harmonize the national legal system relating to the protection, enhancement and transmission of the national cultural heritage with the international criteria to which Morocco has adhered and to integrate the new internationally recognized concepts of heritage ..." (C) http://www.sgg.gov.ma/portals/0/AvantProjet/47/Avp_Loi_52.13_Fr. pdf.) Industrial sites "wastelands, mines, factories or other period installations ...,", and new towns "presenting features of historical, architectural and artistic interest" are included for the first time. In fact, the consideration of industrial heritage was supported by King Mohammed VI in 2014 as part of the Greater Casablanca development project 2015-2020. Nevertheless, despite this promising impetus, safeguarding projects are almost nonexistent.

In fact, in the absence of an inventory, tools, and expertise structures charged with evaluating the potential heritage, the real estate frenzy continues and is taking over the strategic post-industrial territories. Casablanca, which was the laboratory of Neo-classical, Neo-Moorish, Art-Deco and Bauhaus architecture, is ransacking its past and dispossessing itself of its colonial industrial heritage in a careless manner. Faced with this observation, we will try to answer several questions in this article: Is there a colonial industrial heritage in Casablanca? If so, how is it perceived by the population? Are they attached to it in the same way as they are to the existing ancestral heritage, such as the medinas, a UNESCO world heritage site?

\section{FIELD EXPLORATION: METHODOLOGIES AND SURVEYS}

To answer these questions, we borrowed two inductive methodologies from the social sciences in order to have the latitude to go back and forth between the theory and the practice of the territory, and thus obtain a global and strategic vision. Therefore, we chose the qualitative survey method on the one hand and the grounded theory method on the other. Before applying them to our case study, we would like to briefly explain these principles. 


\subsection{Qualitative survey method}

There are several techniques of qualitative investigation: "mapping and documentary surveys, observation procedures, interviews, group interviews, participant observation, etc." Here, we opt for the techniques of observation and interview. Observation precedes the actual survey and aims to understand the situation(s) experienced by the population, the associations, the administration, etc. Observation allows the optimization of the interview and helps to prepare for the recruitment of the different actors of the industrial heritage of Casablanca and to finely detect the interactions between them. It also allows the identification of possible variations between the speeches collected during the interview and the real practices. During this phase, an alternation between "observation sessions" in situ and "reflection and writing sessions" is carried out. The interview allows the issues in the field to be clarified on the basis of the real-life experience of the targeted actors. Each interview is to be considered as expertise in its own right. The specificity of the interview, especially the semi-directive one, is to frame the questioning while giving those interviewed the opportunity to speak freely.

\subsection{Grounded theory methodology}

Grounded Theory (GT) methodology has been around for over fifty years [1]. It is an inductive approach whose objective is to generate theories while proposing a set of procedures to achieve this [2]-[5]. We chose to add this method to the survey for two reasons: on the one hand, it is more flexible than the quantitative method which is based on 'logicodeductive' ("The logico-deductive model of science is to seek truth by testing hypotheses using a pre-existing framework and statistical analysis. The goal of research is to arrive at conclusions that can be generalized to other populations." [5]) reasoning and, on the other hand, it allows the generation and development of theories 'rooted' in the field data. The GT method is also based on the premise that there is not one truth but several truths, depending on one's definition of a given phenomenon; a definition that varies according to time, place, quality of the observer, cotext and context.

The GT approach is inductive. It allows the identification of relevant concepts and to generate a series of hypotheses during the exploration process. There is no question of imposing quantitative research procedures, standards and evaluation criteria. The criteria are derived from the methodology itself during the process. According to Corbin [5], the purpose of a GT exploration does not lie in the recognition of a 'single truth,' or in the testing of hypotheses, but rather in the interpretation of several truths that coexist and that allow us to understand a phenomenon in its context [5]. GT does not exclude quantitative analyses, however, and resorts to rather deductive methods when it comes to confronting theories with data, as its founders confirm [1]. The specificity of the GT method lies in the reversal of the traditional order of the scientific approach. First, we give the advantage to the data, to the field, and then we resort to the scientific literature. Three principles will guide us in this approach:

- The principle of emergence in the work consists of bringing the person who is at the core of the phenomenon to give themselves up and express their lived experience: Let the meaning emerge while confronting it with empirical data to verify its coherence [1]-[4].

- Theoretical sensitivity is the ability to go beyond intuitive interpretation and to look for what is hidden in common sense [2]. 
- Sensitizing concepts are the set of theoretical, experiential or cultural tools and knowledge that will allow us to analyze the empirical data in a relevant way [2].

\section{APPLICATIONS IN THE FIELD: THE INDUSTRIAL HERITAGE OF CASABLANCA - A DIVISIVE CONCEPT}

In order to be able to answer the initial questions and obtain convincing results, we carried out two successive surveys. The first one had a broad vision; the second one was more focused and followed from our first results.

During the observation phase, our mission consisted of observing the field of investigation and rubbing shoulders with its inhabitants, without actually approaching them. During the interview (The survey of the population was mainly conducted in Arabic, the country's first language. Some citizens expressed a certain ease with French, the country's second language. I adapted the interview to the intellectual level of each citizen interviewed. The wording of the questions was adapted and translated simultaneously to facilitate comprehension and extract a maximum amount of information on the subject.) phase, the interviewee was guided in a semi-directive way and had the possibility of leaving the framework if they wished.

\subsection{Survey 1: interpretation of the data}

Several post-industrial districts within Casablanca were chosen at random. A sample of 26 people from all active age groups was studied. This first survey questioned 4 districts in East Casablanca: Mers Sultan - La Gironde, Belvédère - Roches Noires, La Villette, Hay Mohammadi.

Starting from the premise that each interview is unique, each singularity describes a process "at the origin of an action" to be analyzed. This allowed the identification of individual practices and brought out the singular coherences. We can summarize these as follows:

\subsubsection{Denunciation of the structuring and structural problems of the city of Casablanca}

The citizens of the industrial districts in the east of the city broke their silence and dare to denounce the structural problems of the city of Casablanca, which have a direct impact on their territory. The citizens of the industrial districts were primarily concerned about the failure of the health, education, waste management and public transport systems. The economic crisis of the 2008 trapped them in unemployment and over-indebtedness. The abandonment and degradation of certain industrial sites led to a climate of insecurity. Young people are increasingly dropping out of school and a phenomenon of delinquency is gradually taking hold in these mythical districts. The citizens of the industrial districts expressed that they are aware of the recent changes taking place in their district. They understand the speculative stakes and even speak of the "real estate mafia," but until now they have been unaware of the heritage issues. They suffer from densification and have a very difficult time with the gentrification that is taking place on their territory.

\subsubsection{Secondary interest in safeguarding the civil heritage of the city of Casablanca}

After highlighting the dysfunctions, and after having oriented the citizens towards the heritage issue, some of them showed their interest in the Art Deco, Modernist and NeoMoorish civil heritage of the city of Casablanca. They even defended the interest of 
safeguarding and enhancing it, the media coverage and the multiple actions around it being the main factor without any doubt.

\subsubsection{The division of the citizens regarding the symbolism of the industrial past of the city}

In a large majority of the interviews, the disused economic activity sites were accepted to be the result of the colonial period. They are therefore the factories 'of the French,' in opposition to the urban planning and architecture of this same period. A real symbolic separation was present in the mentalities.

Beyond that, when we oriented the discussion and approached the notion of Casablanca's industrial heritage $(\mathrm{CIH})$, the reaction was surprising, to say the least. Although the average citizen was not familiar with this notion and was even surprised by this composition "heritage + industry," they wished and persisted in referring to this heritage as "colonial." By this position, the citizens associated the CIH with the colonial achievement. This is probably an important clarification. The demarcation of the CIH explains, to some extent, why it is not on the list of primary concerns for the citizens of the eastern districts. The colonial CIH is, by its connotation, the work of the other and, in fact, the concern of the other. Although all the citizens agreed on this colonial connotation of the $\mathrm{CIH}$, they were divided as to its evaluation:

- The industrial wastelands and old disused factories are the essence of the city according to the population over 30 years of age.

Citizens over 30 years old were more vocal and explained the symbolism of the witnesses of this past industry. For them, it is, above all, a place of memory, a working-class identity, a working-class culture, a symbol of working-class struggle, an industrial identity, a Casablanca identity, a symbol of progress and glory, a symbol of greatness and prosperity, a symbol of resistance, an architectural landmark, a landscape force, a brand, a sign, a knowhow, an apprenticeship, and unique architecture.

Citizens over 30 were sometimes nostalgic when they talked about sites that have disappeared, sometimes helpless when they talked about sites that are being demolished, and sometimes optimistic when they talked about sites that are still standing. Some citizens over the age of 30 expressed their desolations and regrets: the abandonment of certain sites with great potential, the progressive deindustrialization of industrial districts has caused chaos and social disaster, the insensitivity of young people to the symbolism of their district's industrial past, the progressive change of the territory and the lack of information and participatory consultation with the local inhabitants. In addition, some citizens took advantage of this opportunity to describe and share their expectations: The improvement of the image of the industrial districts by cleaning them up, the demolition and cleaning of abandoned and uninteresting industrial sites, the rehabilitation of sites still standing (in very good condition) and the maintenance of the industrial use, the rehabilitation of resistant sites (in the beginning of degradation) and their reconversion into socio-economic and socio-cultural projects.

This category includes the industrial past, and it remains in all its projections and conditions the improvement of its territory by improving it. It even suggests the 'rebranding' of the city, the 'making the city shine,' and changing the negative image through this industrial past.

- The industrial wastelands and old disused factories are a nuisance and symbolize misery and chaos according to those under 30 . 
For this sample of the population, the vision of disused economic activity sites is quite different. At first sight, they are degraded elements with no future. Objects of the past that symbolize economic and social failures. They are in no way a heritage to be developed. The urban priority is elsewhere.

\subsection{Survey 2: interpretation of the data}

The systematic industrial past denial of the under-30 age group during Survey 1 led to a second survey. The area observed is at the heart of the industrial heritage of East Casablanca. It is located in the "Hay Mohammadi" district. It is the first industrial center of the Greater Casablanca region. This study area was chosen for two major reasons: the abundance of disused industrial sites and ageing working-class housing estates that are still inhabited, and the rejuvenation of the local population, $44.5 \%$ of the inhabitants are under 30 years old.

We therefore have a recognized post-colonial industrial center, a large disused industrial land base and a population from the adjoining working-class housing estates. Moreover, the population that uses these places today, and that is one of the actors of the future of this territory, is increasingly young. All reasons that reinforce the legitimacy of our choice of target.

This study area is close to the slaughterhouses, the disused tanneries, the poultry market, the former shanty town "Douar Ouled Ahmed," which has since been razed to the ground, and the working-class housing estates. The area is in permanent tension and is one of the 264 districts targeted by the INDH ("On 18 May 2005, His Majesty King Mohammed VI gave a historic speech in which he announced the launch of the National Initiative for Human Development (INDH). A large-scale initiative to fight against poverty and exclusion," http://www.maroc.ma/fr/content/indh), which fights against poverty and social exclusion. It represents several deficits: insufficient basic social infrastructure, aging and unhealthy housing, aging and abandonment of several industrial sites, increasing unemployment, impoverishment of the population, increasing school dropout, lack of training and integration opportunities for young people, and lack of quality green spaces.

Given that the challenge of a qualitative survey does not lie in the number of people interviewed but in the way they are interviewed, and their comments are analyzed, 16 people from the Hay Mohammadi district were interviewed (for a listening time of 30 to 60 minutes). Each survey was based on a semi-directive questionnaire and was carried out individually and anonymously if the interviewee so wished.

As a result, the young people did not immediately express themselves on the industrial heritage aspect but more on what concerns them most: the deficiency of the infrastructure, the deficiency of the public education system, unemployment, their uneasiness, etc. The question of industrial heritage only came up halfway through, or even at the end of, each interview. As for the question of heritage, which was of such concern to the over-30s, it was secondary, if not non-existent for the youth. The young people express more interested in the possible reconversion of the heritage than in its preservation or classification. The conversion of industrial wastelands into facilities was stated as more than a wish for these young people, it was an ambition. The ambition to improve their environment and make it sustainable, the ambition to counter the installation of new high-class apartment buildings, the ambition to stop the gradual gentrification of the district and to strengthen the bonds of solidarity between the original inhabitants. 


\section{CASABLANCA'S INDUSTRIAL HERITAGE: THE HERITAGE OF THE OTHER}

In the process of identification and attachment to the territory, heritage appears to be one of the resources allowing this process. It forms a common heritage for a group of individuals and allows a lasting cohesion in time (between the past and the future) and in space (by structuring the territory). From this relationship between heritage and territory emerges a "conceptual kinship" [6]. Heritage, through its production and representations, is a way of "producing fathers" (P. Legendre) [7]. "Producing fathers" was expressed by Pierre Legendre during a debate on the metamorphoses of the notion of heritage and taken up by Henri Pierre Jeudy in the introduction to his book "Patrimoines en folie." Therefore, the process of heritage development expresses a territorial identity and refers to a form of appropriation by human societies [6].

The construction of heritage requires a certain sacredness and reappropriation of a set of achievements, of production objects recognized as witnesses of a civilization and know-how, around which a society or a group recognizes itself and makes itself recognized. When a society appropriates its heritage and exposes it to the public gaze, it is because it wishes to be recognized in this specificity and singularity.

The question then arises: how to appropriate the 'other's' heritage, the 'colonial' heritage? This is the paradox of the Maghreb countries and specifically that of our case study: Morocco.

\subsection{Exploring the colonial past in Morocco}

Although it symbolizes confrontation and violent occupation, the protectorate, strengthened by its Algerian and Tunisian experience, was keen to preserve the local memory and to safeguard a certain identity in the Moroccan Medinas. This is what Arrif [8] describes as "taking charge of the memory of the other." General Lyautey said in this regard: "We arrived in a country which, with Arabia and certain regions of Central Asia, contained the only cities in the world where exoticism had retained its purity. The character of these cities had to be saved ...." It is for this reason that the 'Lyauthean (In reference to General Lyautey)' urbanism practiced in Morocco has been described as the 'urbanism of the protector' versus the 'urbanism of the victor' practiced in Algeria. There are many interpretations, but the majority of Moroccan researchers and historians agree that the colonial construction of heritage and the preservation of Moroccan Medinas representing the "memory of the other," the indigenous, supports the rupture and seals the difference with the latter. The "Old Medina," an ancient territory that shelters and closes in on the natives to isolate them and better control them, versus the "European City," a new territory that meets all the needs of the colonists [8], [9]. What is certain, leaving aside the main motivations of General Lyautey, is that the city of Casablanca developed outside the limits of the Old Medina with the aim of preserving it behind its ramparts and raising it to the level of a sacred heritage.

In 1912, Lyautey created the Department of Antiquities, Fine Arts and Historic Monuments, intended to preserve the heritage of the past and preserve the local memory. From 1924 onwards, the object of heritage evolved, and the classification was extended to the public buildings of the "European City." The law on the preservation and enhancement of the Old Medina was relaxed in 1945 for obvious cultural and hygiene reasons. We retain the dualism of preservation and separation from the colonial construction of heritage in Morocco. Today's Moroccan has made choices and appropriated the colonial heritage, but in what way? Since independence, Morocco has been confronted with the reality of the field 


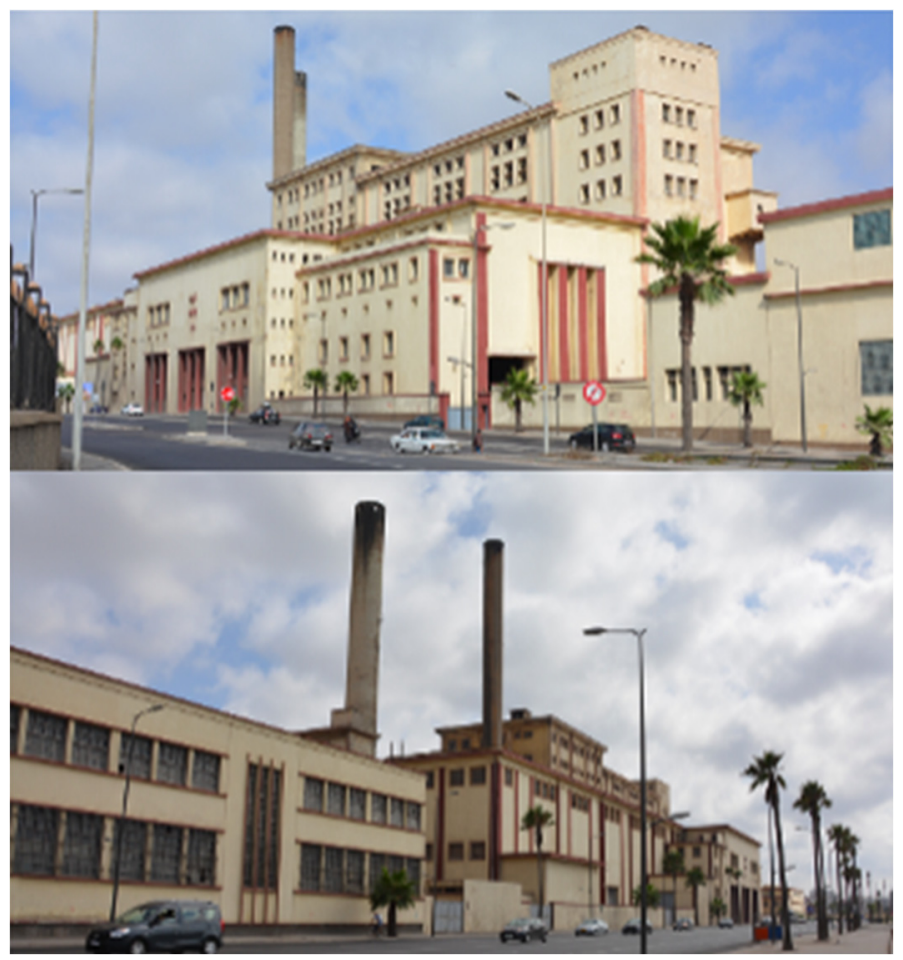

Figure 2: Former installations of the national water and electricity office (O.N.E.E), called the southern power station of Roches Noires, 2018, (C) Seddiki.

and the prevailing dualism. It has had to deal with two references imposed as such by General Lyautey: the indigenous heritage (that of its Muslim ancestors) and the colonial heritage (manufactured by the colonists and inspired by their culture). In fact, the French protectorate transposed the policy of safeguarding applied in metropolitan France in 1912, in order to safeguard a different memory on a different territory. Today, it is Morocco's turn to deal with the memory of the other (the colonist) on its own territory.

\subsection{Industrial heritage in East Casablanca}

At first sight, we could identify that the people of Casablanca are clearly divided on the subject. There is no unanimity on this issue. This new heritage object is in the making and its future is of concern exclusively to the generation over 30 .

As the survey shows, the under-30 generation attaches negative connotations to the world of the factory and refuses to identify with or appropriate this industrial legacy. It is also a generation that considers itself globalist and refuses to take root or to be attached to its territory. It is clearly a generation without an identity, or that is at least in search of one.

The generation over 30 accepts the industrial legacy, the relics passed down from generation to generation, and considers them worthy of protection in various respects. Firstly for their historical, technical and architectural value, expressed by the intellectual stratum. Secondly for their social, memorial and symbolic value, all three of which are advocated by the working-class mass that lived and worked there. The dismantled factory or wasteland 
takes on a symbolic value that acts as a link between the present and the past from which it emerged. Palmer [10] calls this symbolic link, this value of the history and social memory of the place, 'lived experience' [10]. The factories become symbols and icons for this workingclass mass, destined for collective appropriation and identity enhancement. The notion of industrial heritage has the power to transform these places into "sanctuaries of memory" [11].

This quest for identity values can be observed in Western societies from the 1960s and 1970s, which saw the emergence of alternative movements: feminist, anti-nuclear and anticapitalist movements, etc. According to Di Méo [12], this was a time when the younger generation, unlike Moroccan youth, wanted to return to their roots and to what they identified as authenticity. All these currents were characterized by attitudes of opposition to totalitarian values and ideologies. Their obvious infatuation with heritage is what the sociologist Yvon Lamy calls 'return investment' [12].

\section{CONCLUSION}

The role of industrial architecture is intriguing, and its value is still being debated: the factory as a place of experimentation with modernity and architectural innovation, or the factory as a purely rational envelope for increasingly complex machines. Industrial architecture has always evolved between fashion and economic constraints. Hamon and Cartier [13] remind us of the words of the historian of industrialization Jones [14]: “...industrial buildings are, almost as much as the buildings of power (social, royal, etc.) subject to the effects of fashion...." Sometimes it borrows neutral, functional or fashionable forms and sometimes it invents its own complex and innovative forms. It is, moreover, innovation that marks the Moroccan specificity and crystallizes the singularity of colonial industrial architecture in Morocco.

The generation over 30, the most representative, has gone beyond the stage of heritage awareness and its heritage impulse seems to indicate change and to announce the commitment towards a concrete process of heritage. This process cannot exist without actors and a political context which is favorable to the conservation, valorization and exhibition of Moroccan industrial heritage.

The perception of the Casablanca population of the history of their city has changed fundamentally since the publication of the book and the exhibition "Casablanca, birth of a modern city on African ground," at the Villa of Arts in Casablanca in February 2000.

The impact of the book and the exhibition was immediate. The people of Casablanca were finally able to rid themselves of their inferiority complex facing the "legitimate" Moroccan from the imperial cities. For a long time, Casablanca was considered by the bourgeoisie of the imperial cities of Fez, Rabat or Marrakech as a new colonial city with no historical value, no cultural value and no interest.

Through the knowledge of the heritage, the Casablanca citizen finally found the material means to speak about the history of their city and to defend their identification with it.

This improved knowledge of a heritage that has long been despised does not go beyond the circle of academics and does nothing to stop the cycle of destruction. The demagogic division of Casablanca into 29 communes at the time created a state of incoherence conducive to speculators.

Today, the destruction continues and fills the lack of plots in a city that is renewed daily.

The long-sought identity of Casablanca's citizens is being decimated by real estate fever and speculative interests [3], [15]. In fact, it is more necessary than ever to accompany the various heritage actors in the heritage process and to equip them in an efficient manner. 


\section{REFERENCES}

[1] Glaser, B. \& Strauss, A., The Discovery of Grounded Theory: Strategies for Qualitative Research, Aldine: Chigago, 1967.

[2] Corbin, J. \& Strauss, A., Basics of Qualitative Research, Thousand Oaks, 2008.

[3] Glaser, B., The Grounded Theory Perspective: Conceptualization Contrasted with Description, Sociology Press: Mill Valley, 2001.

[4] Laperrière, A., La Théorisation Ancrée (Grounded Theory): Démarche analytique et comparaison avec d'autres approches apparentées. La recherche qualitative: enjeux épistémologiques et méthodologiques, G. Morin: Boucherville, pp. 309-340, 1997.

[5] Corbin, J., Préface: Méthodologie de la théorisation enracinée. Fondements, Procédures et Usages, Presses de l'Université du Québec: Montréal, 2012.

[6] Di Meo, G., Patrimoine et territoire, une parenté conceptuelle. Espaces et Sociétés, 78(4), pp. 15-35, 1994.

[7] Jeudy, H.P., Introduction: Patrimoines en Folie, Editions de la Maison des sciences de l'homme: Paris, 1990.

[8] Arrif A., Le paradoxe de la construction du fait patrimonial en situation coloniale. Le cas du Maroc. Figures de l'orientalisme en Architecture, 73-74, 1996.

[9] Cattedra, R., Casablanca: La réconciliation patrimoniale comme enjeu de l'identité urbaine. Rives Nord-Méditéranéennes, 2003.

[10] Palmer, M., Understanding the workplace: A research framework for industrial archaeology. Industrial Archaeology Review, 2005.

[11] Lucas, P., La religion de la vie Quotidienne, PUF: Paris, 1981.

[12] Di Méo, G., Processus de patrimonialisation et construction des territoires. Patrimoine et industries en Poitou-Charentes: Connaitre, Poitiers-Châtellerault, 2007.

[13] Hamon, F. \& Cartier, C., L'architecture industrielle, travaux et publications, un bilan international. Revue de l'Art, 79, pp. 52-62, 1988.

[14] Jones, E., Industrial Architecture in Britain, 1750-1939, Bastford: London, 1985.

[15] Toulier, B. \& Pabois, M., Architecture Coloniale et Patrimoine: L'expérience Française, Institut National du Patrimoine: Paris, 2003. 